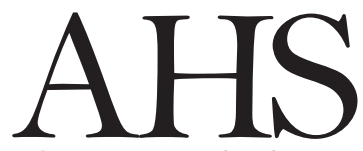

Advances in Horticultural Science

\title{
Foliar application of potassium on antioxidant enzyme activities of tomato plants under drought stress
}

\author{
A. Farzane ${ }^{1}$, H. Nemati ${ }^{1}{ }^{(*)}$, M. Shoor ${ }^{1}$, H. Ansari ${ }^{2}$ \\ 1 Department of Gardening, Faculty of Agriculture, Ferdowsi University \\ of Mashhad, Iran. \\ 2 Department of Water Engineering, Faculty of Agriculture, Ferdowsi \\ University of Mashhad, Iran.
}

Key words: Catalase, evapotranspiration, $\mathrm{KCl}$, polyphenol oxidase, superoxide dismutase.

OPEN ACCESS

(*) Corresponding author: $_{\text {nemati@um.ac.ir }}$

Citation:

FARZANE A., NEMATI H., SHOOR M., ANSARI H., 2021 - Foliar application of potassium on antioxidant enzyme activities of tomato plants under drought stress. - Adv. Hort. Sci., 35(1): 3-9

Copyright:

(C) 2021 Farzane A., Nemati H., Shoor M., Ansari $H$. This is an open access, peer reviewed article published by Firenze University Press

(http://www.fupress.net/index.php/ahs/) and distributed under the terms of the Creative Commons Attribution License, which permits unrestricted use, distribution, and reproduction in any medium, provided the original author and source are credited.

Data Availability Statement: All relevant data are within the paper and its Supporting Information files.

Competing Interests:

The authors declare no competing interests.

Received for publication 16 April 2020 Accepted for publication 24 Dcember 2020
Abstract: Water stress negatively affects productivity in crops, while the foliar application of potassium-containing compounds may be helpful in reducing the drought effects. This study evaluated the efficacy of foliar applied potassium chloride (control - distilled water spray -, 3 and $6 \mathrm{mM}^{-1}$ ) on tomato plants under drought stress. Three irrigation levels were maintained at 100, 75 and $50 \%$ according to evapotranspiration designated as well watered, moderate and severe drought stressed. Increasing drought stress significantly reduced plant growth and yield. The foliar applied $\mathrm{KCl}$ produced maximum leaf area, stem diameter and length, plant yield under each drought stress conditions compared to control. The minimum of growth factors were obtained by control under severe stress. Highest yield per plant was also recorded for foliar applied $\mathrm{KCl}$ under moderate condition than other treatments. Foliar applied $\mathrm{KCl}$ alone decreased the SOD, CAT and PPO in well-watered condition but $\mathrm{KCl}$ application on tomato plants under drought stress induced the antioxidant enzyme activities more than control well-watered treatment.

\section{Introduction}

The major limitation for plant growth and crop production in arid and semi-arid regions is soil water availability. Plants that are continuously exposed to drought stress can form ROS (Reactive oxygen species), which leads to leaf damage (Foyer et al., 2002; Oerke and Dehne, 2004; Cakmak, 2005) and, ultimately, decreases crop yield. The decrease in soil water potential causes alteration in minerals uptake by plant roots and reduction in leaf expansion under drought stress conditions (Kaminek et al., 1997; Pospisilova et al., 2000).

Drought is becoming a serious threat to crop production worldwide resulting in 67 and $82 \%$ reduction in $\mathrm{K}$ uptake under mild and severe water stress conditions (Baque et al., 2006). During drought stress, root growth and the rates of $\mathrm{K}^{+}$diffusion in the soil towards the roots were 
both restricted, thus limiting $\mathrm{K}$ acquisition. The resulting lower $K$ concentrations can further depress the plant resistance to drought stress, as well as $\mathrm{K}$ absorption, which ultimately leads to reduction in the fruit size, plant yield, lack in red color of tomato and fruit quality (Bidari and Hebsur, 2011; Afzal et al., 2015), and deteriorated photosynthesis, enzyme activation in plants (Marschner, 1995; Garg et al., 2004; Afzal et al., 2015). Maintaining adequate plant $\mathrm{K}$ is, therefore, critical for plant drought resistance.

When plants were supplied with different $\mathrm{K}^{+}$concentrations and then subjected to drought stress, their stomatal conductance was more markedly reduced in normal $\mathrm{K}$ plants than in low $\mathrm{K}$ plants (Wang et al., 2013). During drought stress, the stomata cannot function properly in $\mathrm{K}^{+}$-deficient plants, resulting in greater water loss. Drought stress did not decrease water use efficiency (WUE), whereas it did increase WUE by rapid stomata closing during water deficit (Egilla et al., 2005). Adequate levels of $\mathrm{K}$ nutrition enhanced plant drought resistance, water relations, WUE and plant growth under drought conditions (Wang et al., 2013). Besides various adaptive mechanisms; potassium (K) sprayed under drought condition can improve the tolerance of crop plants to various types of abiotic stresses, and it also improved subsequent growth and yield. Mengel and Kirkby (2001) reported that $\mathrm{K}$ improves physiological processes by the regulation of turgor pressure and photosynthesis; translocation of cations and enzymes activation, while, Cakmak (2005) also observed that plant suffering from drought stress required more internal $\mathrm{K}$. Yield limiting effect of water deficit could be overcome by increasing K supply (Damon and Rengel, 2007). In legumes, devastating effects of drought can be alleviated by rich $\mathrm{K}$ supply (Sangakkara et al., 2000). A close relationship between $K$ nutritional status and plant drought resistance has been demonstrated.

The bottom lines of the reviewed results in this section indicate that under drought stress conditions, yield losses can be minimized by the sufficient supply of K. However, its application effect at tomato growth stages is not well understood yet. The objective of present work was to study the possible role of $\mathrm{K}$ applied on tomato plant under drought, in mitigation of stress in terms of physiological components and antioxidant enzyme values.

\section{Materials and Methods}

This experiment was designed to observe the effect of $\mathrm{KCl}$ on tomato (Solanum lycopersicum L.) seedlings under drought stress. Seeds of tomato were sown in plastic trays and maintained in a greenhouse up to 4 real leafy stages, at Department of Horticulture, Faculty of Agriculture, Ferdowsi University of Mashhad, Iran. The experimental design was a split plot design with three water stress plot as main plot and $3 \mathrm{KCl}$ treatments $\left(0,3\right.$ and $\left.6 \mathrm{mM}^{-1}\right)$ as subsidiary plot with 3 replications. The subsidiary plot area was $1 \mathrm{~m}^{2}(1 \times 1 \mathrm{~m})$ and consisted of four plants per plot. After 70 days from sowing, seedlings with uniform growth were transplanted to an experimental field with a $50 \mathrm{~cm}$ inter-seedling spacing. According to evapotranspiration $\left(E T_{c}=\right.$ crop evapotransipration), the water stress was conducted on tomato plants at three levels well-watered (100\% $\mathrm{ET}_{\mathrm{c}}$ ), moderate and severe drought stress (75 and $50 \% \mathrm{ET}_{c}$, respectively). According to PenmanMonteith equation, the crop evapotranspiration, ETc (Formula 1), is calculated by multiplying the reference crop evapotranspiration, ETo, by a crop coefficient, Kc and ETo (Formula 2) is calculated by Ep and Kp factors.

$$
\mathrm{ET}_{\mathrm{c}}=\mathrm{K}_{\mathrm{c}} \mathrm{ET}_{\mathrm{o}}
$$

Where $\mathrm{ETC}=$ crop evapotranspiration $\left[\mathrm{mm} \mathrm{d}^{-1}\right], \mathrm{Kc}=$ crop coefficient [1.15 for tomato], ETo= crop evapotranspiration $\left[\mathrm{mm} \mathrm{d}^{-1}\right]$.

$$
E T o=E p . K p
$$

Where $\mathrm{Kp}=$ Pan coefficient $(0.77)$, Ep0 pan evaporation.

The foliar spray was applied five times (during two month) to tomato plants during growth and fruit set with $\mathrm{KCl}$ at 0,3 and $6 \mathrm{mM}^{-1}$ dose.

\section{Growth and plant analysis}

Plant height and stem diameter were measured at the end of the harvesting season and presented as $\mathrm{cm}$ and $\mathrm{mm}$ respectively. The total yield of tomato fruits were measured by gram scales $(\mathrm{g})$ in different harvesting times per plant. The leaf area (LA) measured by Windias (Delta-T Co, England) and presented as $\left(\mathrm{mm}^{2}\right)$.

The integrated water-use efficiency (formula 3 ) is typically defined as the ratio of biomass produced (D, $\left.\mathrm{kg} \mathrm{h}^{-1}\right)$ to the rate of total water irrigation $\left(\mathrm{W}_{\mathrm{i}}, \mathrm{m}^{3} \mathrm{ha}^{-1}\right)$ and rainfall $\left(W_{p}, \mathrm{~mm}\right)$ during the drought stress treat- 
ment.

$$
W U E=D /(W p+W i)
$$

\section{Assays of enzymatic and non-enzymatic antioxidants}

Fruits were randomly selected from each treatment, at the end of the experiment. Total soluble proteins were quantified by following the protocol devised by Bradford (1976). For determination of enzymatic antioxidants, fruit samples were extracted in $50 \mathrm{mM}$ phosphate buffer ( $\mathrm{pH} 7.8)$. The extract was centrifuged at $15,000 \mathrm{rpm} 4^{\circ} \mathrm{C}$ and the supernatant was used for further assay of catalase (CAT) Chance and Maehly, 1955 and poly phenol oxidase (PPO) (Siriphanich and Kader, 1985) and super oxide dismutase (SOD) activities (Giannopolitis and Ries, 1977). Tomato juice was squeezed from the fresh tomatoes onto a digital refractometer (PR-100, Atago Co. Ltd., Tokyo, Japan) to measure total soluble solids (TSS) and the results were expressed in Brix according to AOAC method 932.12 (2005). For measured the proline content, leaves were randomly selected and experimented according to Bates et al. (1973) method.

\section{Statistical analysis}

Effects of water stress treatments; $\mathrm{KCl}$ and corresponding interactions were determined by analysis of variance according to the general linear model procedure of SAS (version 8.2; SAS Institute, Cary, N.C.). Means were compared using Least Significant Difference $(\angle S D, p \leq 0.05)$ according to method described by Tukey HSD. Analysis showed a significant interaction between $\mathrm{KCl}$ and watering treatment for the some measured parameters. The graphs draw by using excels 2010 software.

\section{Results}

Increasing drought stress (DS) levels significantly reduced plant growth and yield, but foliar applica- tions of $\mathrm{KCl}$ improved the harmful effects of drought stress.

Comparison of means indicate that leaf area (LA) was gradually decreased with increasing drought stress (Table 1). The minimum leaf area was obtained under extreme drought conditions (50\% ETc). Water stress decreased LA but exogenous application of $\mathrm{KCl}$ ameliorated the negative effects of water stress significantly than water spray only (Fig. 1a). However, highest LA in each treatment was recorded for foliar applied $\mathrm{KCl}$ than control under well-watered, moderate and severe drought stress. A minimum LA was recorded under severe drought stress, especially control $\times 50 \%$ ETc treatment (Fig. 1a).

The increasing water stress decreased stem length (Fig. 1b). A maximum stem length was observed under well-watered conditions by exogenous application of $6 \mathrm{mM}^{-1} \mathrm{KCl}$ while in moderate and severe drought, foliar applied $\mathrm{KCl}$ had no significant effects. Minimum stem length was noted under extreme water stress without foliar $\mathrm{KCl}$ application. Stem diameter decrease in response to DS (Table 1). Foliar $\mathrm{KCl}$ application helps to plant tolerance with increasing stem diameter under DS condition. Data showed (Fig. 1c) the increasing in $\mathrm{KCl}$ doses ( 0 up to $6 \mathrm{mM}^{-1}$ ) lead to increasing in stem diameter in all of treatments.

The tomato yield displayed a significant reduction in response to the increasing levels of water deficit treatments. For example, under effect of $50 \%$ ETc condition, the yield decreased by $21 \%$ (Table 1) compared to control. In the other hand, plants had more vegetative growth and less yield in well-watered condition (100\% ETc) than moderate DS (75\% ETc). In non-DS condition, foliar spray of $\mathrm{KCl}$ showed similar fruit yield under well-watered, moderate and severe drought conditions. But foliar $\mathrm{KCl}$ application had effective enhancement on plant yield under drought stress (Fig. 1d). Tomatoes irrigated with 50\% ETc without $\mathrm{KCl}$ foliar application also produced fruits with significantly higher juice brix value than other

Table 1 - Effects of different drought stress levels on tomato plants

\begin{tabular}{|c|c|c|c|c|c|c|c|c|c|c|c|}
\hline Drought & $\begin{array}{c}\mathrm{LA} \\
\left(\mathrm{mm}^{2}\right)\end{array}$ & $\begin{array}{l}\text { St. } \\
\text { Length } \\
(\mathrm{cm})\end{array}$ & $\begin{array}{c}\text { St. } \\
\text { Diameter } \\
(\mathrm{mm})\end{array}$ & WUE & $\begin{array}{l}\text { Yield } \\
\text { plant }^{-1}\end{array}$ & Brix $^{0}$ & $\begin{array}{l}\text { Proline } \\
\text { ( } \mu \mathrm{g} / \mathrm{g} . \mathrm{fw})\end{array}$ & $\begin{array}{l}\text { Protein } \\
\left(\mathrm{mg} \mathrm{g}^{-1} \mathrm{fw}\right)\end{array}$ & $\begin{array}{l}\text { SOD } \\
\text { (IU } \mathrm{mg}^{-1} \mathrm{~min}^{-1} \\
\text { protein) }\end{array}$ & $\begin{array}{c}\text { CAT } \\
\text { (IU mg } \mathrm{min}^{-1} \mathrm{~min}^{-1} \\
\text { protein) }\end{array}$ & $\begin{array}{c}\text { PPO } \\
\text { (IU mg }{ }^{-1} \mathrm{~min}^{-1} \\
\text { protein) }\end{array}$ \\
\hline Control & $7555.156 a$ & $52.66 \mathrm{a}$ & $14.69 \mathrm{a}$ & $4.360 \mathrm{~b}$ & $1225.861 \mathrm{a}$ & $7.00 \mathrm{~b}$ & $6734.877 \mathrm{c}$ & $1.405 \mathrm{a}$ & $967.28 \mathrm{a}$ & $178.35 \mathrm{c}$ & $80.777 \mathrm{~b}$ \\
\hline $75 \%$ ETc & $5464.41 b$ & $47.44 \mathrm{~b}$ & $14.41 \mathrm{a}$ & $6.187 \mathrm{a}$ & $1404.72 \mathrm{a}$ & $7.11 b$ & $9468.355 \mathrm{a}$ & $1.540 \mathrm{a}$ & $1240.31 \mathrm{a}$ & $196.63 \mathrm{~b}$ & $142.66 \mathrm{~b}$ \\
\hline $50 \%$ ETc & 3294.32 c & $42.66 \mathrm{c}$ & $11.82 \mathrm{~b}$ & $2.462 \mathrm{c}$ & $963.62 b$ & $7.722 \mathrm{a}$ & $8161.222 b$ & $1.382 \mathrm{a}$ & $1133.79 a$ & $207.83 \mathrm{ab}$ & $258.11 \mathrm{a}$ \\
\hline
\end{tabular}

Means in each column followed by similar letters are not significantly different at 0.05 probability level, using LSD (Least Significant Difference) test. 
treatments (Fig. 1e).

The results in figure 1 (f) revealed that DS on tomato had higher significantly record in water use efficiency than those normally irrigated. Because of fewer yield in control treatment than $75 \%$ ETc, the results affirmed that the treatment $75 \% \mathrm{ETC}$ and then control showed the highest water use efficiency than $50 \%$ ETc treatments. Foliar application of $\mathrm{KCl}$ had no significant effects of WUE under non-DS condition. Finally, the foliar application of $\mathrm{KCl} \times 75 \% \mathrm{ETc}$ showed the highest significant record in WUE in plants subjected to DS, respectively. Meanwhile, the treatment $6 \mathrm{mM}^{-1} \mathrm{KCl} \times 75 \%$ ETc recorded the highest

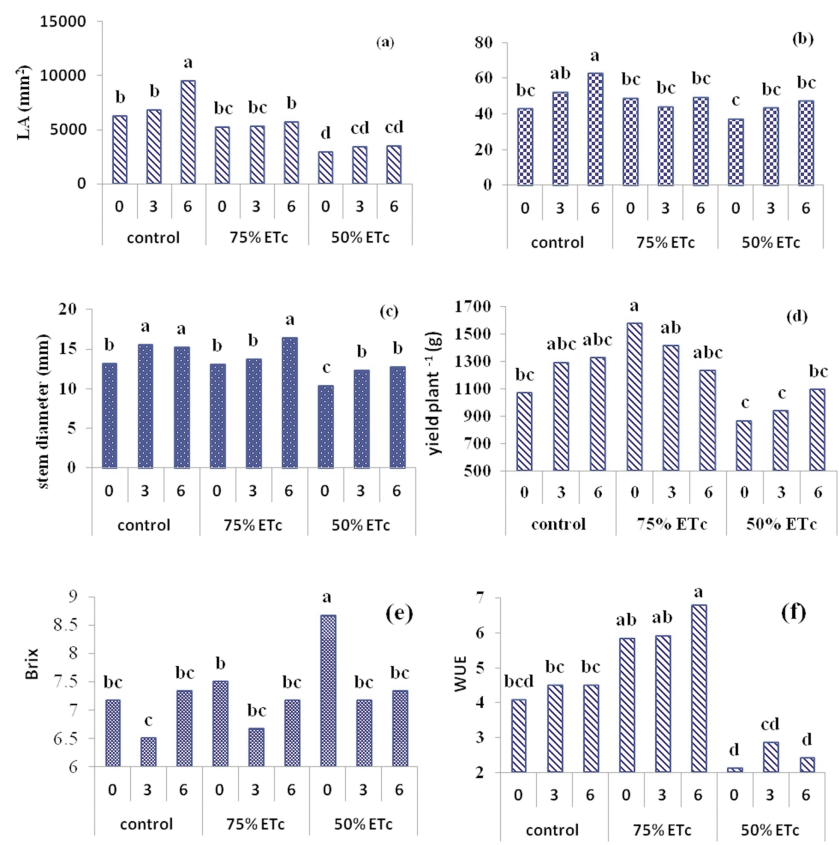

Fig. 1 - Effect of exogenous application of different KCL level on leaf area (a), stem length (b), stem diameter (c), yield (d), Brix (e), and WUE (f) of tomato under drought conditions. (LSD, $p \leq 0.05)$. significant WUE compared to other studied treatments under well-watered and sever DS.

Leaf proline concentration responded differently to drought and K supply. Drought stress (Table 1) increased proline concentration in leaves but exogenous $\mathrm{KCl}$ decreased the proline content under none DS conditions (Table 2). The tomato leaves were sprayed with $\mathrm{KCl}$ had more proline content under drought stress than control conditions (Fig. 2 a). At 0 $\mathrm{mM}^{-1} \mathrm{KCl}$ level with no $\mathrm{DS}$, the proline content in leaves was $1168.4 \mu \mathrm{M} / \mathrm{g}$ F.wt. which increased to 13368.5 and $12111.5 \mu \mathrm{M} / \mathrm{g}$ F.wt. with increasing DS stress in $50 \%$ ETc with 3 and $6 \mathrm{mM}^{-1} \mathrm{KCl}$ foliar application, respectively.

Increase in $\mathrm{KCl}$ doses enhanced the total soluble proteins in tomato fruits (Table 2 ). Maximum fruit protein content was evident at moderate stress with $3 \mathrm{mM}^{-1} \mathrm{KCl}$ followed by $0 \mathrm{mM}^{-1} \mathrm{KCl}$ with minimum value under well-watered conditions (Fig. 2b). Foliar spray with $\mathrm{KCl}$ had impressive effects on protein contents under well-watered and drought stress. However, the exogenous application of $\mathrm{KCl}$ performed better than control for fruit total soluble protein.

A rise in drought stress also amplified the antioxidants status of tomato fruits (Fig. 2c, d, e). Results showed that the enzymatic antioxidant contents in tomato fruits were sprayed by $\mathrm{KCl}$, were decreased. So, the maximum SOD with no significant differences were recorded for foliar applied 0 and $3 \mathrm{mM}^{-1} \mathrm{KCl}$ under severe drought and $0 \mathrm{mM}^{-1} \mathrm{KCl}$ under moderate conditions (Fig. 2c). Increased CAT activities with no significant differences were found under medium and severe drought stress (Fig. 2d). Decreasing water level increased PPO contents for all treatments (Fig. 2e) and the highest value of PPO was obtained under sever DS but increasing in foliar application of $\mathrm{KCl}$ doses from 0 to $6\left(\mathrm{~m}^{-1}\right)$ caused to decrease the PPO fruit content (Fig. 2e).

Table 2 - Foliar application effects of different $\mathrm{KCl}$ levels on tomato plants

\begin{tabular}{|c|c|c|c|c|c|c|c|c|c|c|c|}
\hline $\mathrm{KCl}$ & $\mathrm{LA}\left(\mathrm{mm}^{2}\right)$ & $\begin{array}{l}\text { St. } \\
\text { Length } \\
(\mathrm{cm})\end{array}$ & $\begin{array}{c}\text { St. } \\
\text { Diameter } \\
(\mathrm{mm})\end{array}$ & WUE & $\begin{array}{l}\text { Yield } \\
\text { plant }^{-1}\end{array}$ & Brix $^{0}$ & $\begin{array}{l}\text { Proline } \\
(\mu \mathrm{g} / \mathrm{g} \mathrm{fw})\end{array}$ & $\begin{array}{l}\text { Protein } \\
\left(\mathrm{mg} \mathrm{g}^{-1} \mathrm{fw}\right)\end{array}$ & $\begin{array}{c}\text { SOD } \\
\text { (IU } \mathrm{mg}^{-1} \mathrm{~min}^{-1} \\
\text { protein) }\end{array}$ & $\begin{array}{c}\text { CAT } \\
\text { (IU } \mathrm{mg}^{-1} \mathrm{~min}^{-1} \\
\text { protein) }\end{array}$ & $\begin{array}{c}\text { PPO } \\
\text { (IU } \mathrm{mg}^{-1} \mathrm{~min}^{-1} \\
\text { protein) }\end{array}$ \\
\hline Control & $4836.40 \mathrm{~b}$ & $43.11 \mathrm{~b}$ & $12.23 \mathrm{c}$ & $4.014 \mathrm{a}$ & $1168.46 \mathrm{a}$ & $7.777 \mathrm{a}$ & $8953.16 a$ & $1.286 \mathrm{~b}$ & $1539.26 \mathrm{a}$ & $230.56 \mathrm{a}$ & $167.44 a b$ \\
\hline 3 & $5197.64 \mathrm{~b}$ & $46.55 \mathrm{~b}$ & $13.88 \mathrm{~b}$ & $4.426 \mathrm{a}$ & $1211.41 \mathrm{a}$ & $6.777 \mathrm{ab}$ & $7590.68 c$ & $1.562 \mathrm{a}$ & $761.61 \mathrm{~b}$ & $196.29 \mathrm{ab}$ & $204.66 \mathrm{a}$ \\
\hline 6 & $6279.84 \mathrm{a}$ & $53.11 \mathrm{a}$ & $14.81 \mathrm{a}$ & $4.014 \mathrm{a}$ & $1214.32 \mathrm{a}$ & $7.277 \mathrm{~b}$ & $7820.60 \mathrm{~b}$ & $1.479 \mathrm{ab}$ & $1040.52 a b$ & $155.96 \mathrm{~b}$ & $109.44 \mathrm{~b}$ \\
\hline
\end{tabular}

Means in each column followed by similar letters are not significantly different at 0.05 probability level, using LSD (Least Significant Difference) test. 


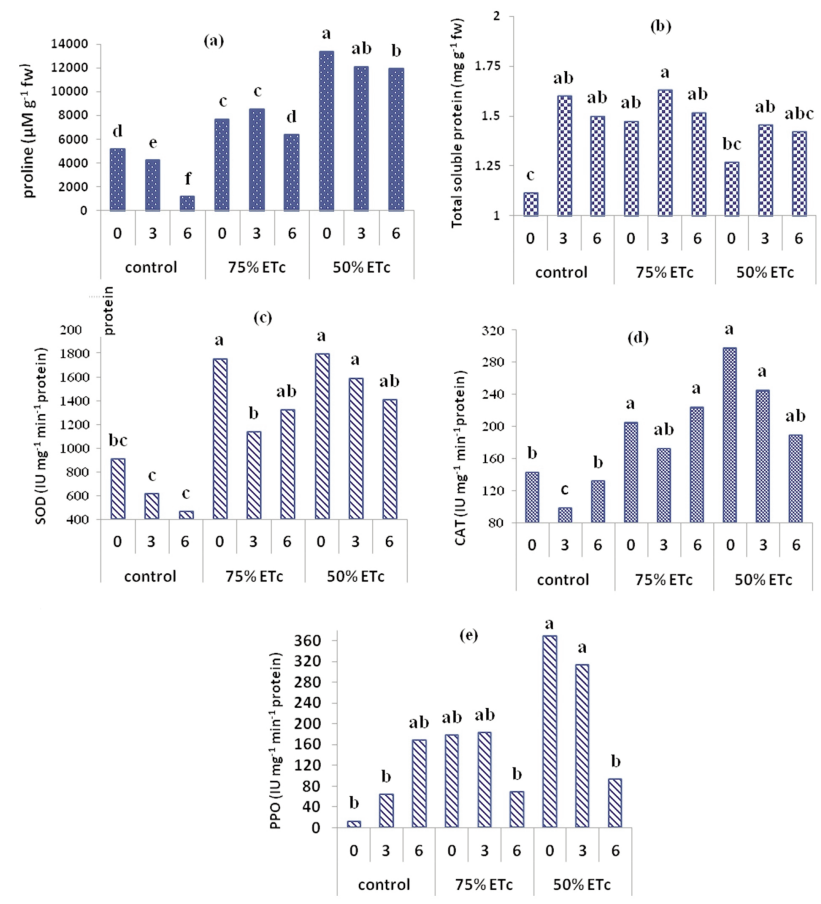

Fig. 2 - Effect of exogenous application of different $\mathrm{KCl}$ levels on enzymatic and non-enzymatic antioxidants; proline (a), total soluble protein (b), superoxide dismutase (c), catalase (d) and polyphenol oxidase (e) of tomato fruits under drought conditions. (LSD, $p \leq 0.05$ ).

\section{Discussion and Conclusions}

Increasing water stress has direct impact on crop growth and yield reduction and similar observations for reduction in growth and fruit yield of tomato were found in present study. Reduction in tomato yield under restricted water availability might have been due to reduction in photosynthetic area such as leaf area and leaf number (Chaves et al., 2011; Khan et al., 2015). In the present study, yield, leaf area and stem length were drastically reduced due to drought effect, whilst $\mathrm{KCl}$ foliar application improved these characters in tomato plants.

It has been reported that the foliar application of $\mathrm{KCl}$ improved the growth factors in agronomy crops (Ahmad and Jabeen, 2005; Yasmeen et al., 2013). Besides adaptation role, positive effect of $\mathrm{KCl}$ on protein contents was also pronounced under drought stress. Proline is a well-known amino acid that generally accumulates when plants are exposed to environmental stresses (Kavi-Kishor et al., 2005). Enhanced proline synthesis is a common response of tomato plants to drought and may determine the stress tolerance (Doan and Maurel, 2005; Khan et al.,
2015). Proline is believed to acts as a signaling molecule that initiates adaptation to the stress (Maggio et al., 2002), acts as osmolyte for osmotic adjustment (Hayat et al., 2012), helps in stabilizing membranes/proteins and scavenges free radicals (Ashraf and Foolad, 2007). Thus, it decreases the adverse effects of cytoplasmic acidosis and maintains proper NADP ${ }^{+}$/NADPH ratios (Liang et al., 2013). In plants grown under drought conditions, proline induces the expression of drought stress responsive genes and, thus, decreases the damage due to excessive $\mathrm{Na}^{+}$ions accumulation (Chinnusamy et al., 2005). Proline act as a compatible solute in the plants (Mansour, 2000) and, generally, increases with increase in both the salinity stress and drought stress duration (Kishor and Sreenivasulu, 2014). Thus, it is likely to observe enhanced proline synthesis with increasing drought stress duration. Antioxidant enzymes activities were considered as indicators of scavenging ROS and reducing oxidative stress (DionisioSese and Tobita, 1998; Lin and Kao, 2002). For example, SOD may convert superoxide radicals into $\mathrm{H}_{2} \mathrm{O}_{2}$ and $\mathrm{H}_{2} \mathrm{O}_{2}$ was further decomposed by CAT and POD (Redman et al., 2011). In this study, drought stress significantly increased the antioxidant enzymes activities. The results of many researchers' studies proved that adequate external K supply significantly decreased antioxidant enzymes activities and proline in drought stressed plants might be caused by enhancing plant physiological metabolism and reducing ROS production and MDA content (Wei et al., 2013; Yasmeen et al., 2013; Bahrami-Rad and Hajiboland, 2017). In the other hand, the combination of drought stress and exogenous $\mathrm{KCl}$ application improved the antioxidant activities and proline content than wellwatered conditions. So, rise in drought stress with exogenous application of $\mathrm{KCl}$ induce tolerance in crops (Yasmeen et al., 2013). A similar trend was followed by all the treatments in case of antioxidant enzyme activities under each water stress treatment.

The results of this study clearly demonstrated that water deficit at any critical crop growth stage severely affected the physiological and antioxidant and non-antioxidant parameters of tomato. Foliar application of $\mathrm{K}$ on a drought stressed plants at all growth stages improved the physiological performance and plant tolerance but reduced antioxidant enzyme activities. All these findings lead us to recommend that for tomato crop under drought farmers should spray the crop with $6\left(\mathrm{~m} \mu^{-1}\right) \mathrm{KCl}$ to minimize the negative effect of drought. This can have a dual benefit: 
improving the physiological performance of tomato and supplying $\mathrm{K}$ nutrient to plants. For the foliar spray on a small scale, a common hand-boom sprayer can easily be used, whereas on large scale use of a mechanical boom-sprayer is advised.

\section{Acknowledgements}

The authors are highly thankful to Faculty of agriculture, Ferdowsi University of Mashhad, Iran for providing funds to complete this study which was a part of a research project entitled "Study on effective treatments to improve water use efficiency at different levels of drought stress on quantitative and qualitative characteristics of tomato (Solanum lycopersicon L.)".

\section{References}

AFZAL I., HUSSAIN B., BASRA S.M.A., HABIB ULLAH S., SHAKEE Q., KAMRAN M., 2015 - Foliar application of potassium improves fruit quality and yield of tomato plants. - Acta. Sci. Pol., Hortorum Cultus., 14(1): 3-13.

AHMAD R., JABEEN R., 2005 - Foliar spray of mineral elements antagonistic to sodium-a technique to induce salt tolerance in plants growing under saline conditions. - Pak. J. Bot., 37: 913-920.

ASHRAF M., FOOLAD M.R., 2007 - Roles of glycine betaine and proline in improving plant abiotic stress tolerance. Environ. Expt. Bot., 59: 206-216.

BAHRAMI-RAD S., HAJIBOLAND R., 2017 - Effect of potassium application in drought-stressed tobacco (Nicotiana rustica L.) plants: Comparison of root with foliar application. - Ann. Agric. Sci., 62: 121-130.

BAQUE M.A., KARIM M.A., HAMID A., TETSUSHI H., 2006 Effect of fertilizer potassium on growth, yield and nutrient uptake of wheat (Triticum aestivum) under water stress conditions. - South Pacific Stud., 27: 25-36.

BATES L.S., WALDREN R.P., TEARE I.D., 1973 - Rapid determination of free proline for water stress studies. - Plant Soil., 39: 205-207.

BIDARI B.I., HEBSUR N.S., 2011 - Potassium in relation to yield and quality of selected vegetable crops. Karnataka J. Agric. Sci., 24(1): 55-59.

BRADFORD M.M., 1976 - A rapid and sensitive method for quantitation of microgram quantities of protein utilizing the principle of protein-dye binding. - Anal. Biochem., 72: 248-254.

CAKMAK I., 2005 - The role of potassium in alleviating detrimental effects of abiotic stresses in plants. - J. Plant Nutr. Soil Sci., 168: 521-530.

CHAVES M., COSTA J.M., SAIBO N.J.M., 2011 - Recent advances in photosynthesis under drought and salinity.
- Adv. Bot. Res., 57: 49-104.

CHINNUSAMY V., JAGENDORF A., ZHU J.K., 2005 Understanding and improving salt tolerance in plants. Crop Sci., 45: 437-448.

DAMON P.M., RENGEL Z., 2007 - Wheat genotypes differ in potassium efficiency under glasshouse and field conditions. - Aust. J. Agric. Res., 58: 816-823.

DIONISIO-SESE M.L., TOBITA S., 1998 - Antioxidant responses of rice seedlings to salinity stress. - Plant Sci., 135: 1-9.

DOAN T.L., MAUREL C., 2005 - Aquaporin In a challenging environment: molecular gears for adjusting plant water status. - Plant Cell Environ., 28: 85-96.

EGILLA J.N., DAVIES F.T., BOUTTON T.W., 2005 - Drought stress influences leaf water content, photosynthesis, and water-use efficiency of hibiscus rosa-sinensis at three potassium concentrations. - Photosynthetica, 43: 135-140.

FOYER C.H., VANACKER H., GOMEZ L.D., HARBINSON J., 2002 - Regulation of photosynthesis and antioxidant metabolism in maize leaves at optimal and chilling temperatures: Review. - Plant Physiol. Biochem., 40: 659-668.

GARG B.K., BURMAN U., KATHJU S., 2004 - The influence of phosphorous nutrition on the physiological responose of moth bean genotypes to drought. - J. Plant Nut. Soil Sci., 167: 503-508.

GIANNOPOLITIS C.N., RIES S.K., 1977 - Superoxide dismutase. I. Occurrence in higher plants. - Plant Physiol., 59: 309-314.

HAYAT S., HAYAT Q., ALYEMENI M.N., WANI A.S., PICHTEL J., AHMAD A., 2012 - Role of proline under changing environments: A review. - Plant Signal Behav., 7(11): 1456-1466.

KAMINEK M., MOTYKA V., VANKOVA R., 1997 - Regulation of cytokinin content in plant cells. - Physiol. Plant., 101: 689-700.

KAVI-KISHOR P.B., SANGAM S., AMRUTHA R.N., SRI-LAXMI P., NAIDU K.R., RAO K.R.S.S., RAO S., REDDY K.J., THERIAPPAN P., SREENIVASULU N., 2005 - Regulation of proline biosynthesis, degradation, uptake and transport in higher plants: Its implications in plant growth and abiotic stress tolerance. - Curr. Sci., 88(3): 424-438.

KHAN S.H., KHAN A., LITAF U., SHAH A.S., KHAN M.A., BILAL M., Ali M.U., 2015 - Effect of drought stress on tomato cv. Bombino. - J. Food Process. Technol., 6(7): 465.

KISHOR P.B.K., SREENIVASULU N., 2014 - Is proline accumulation per se correlated with stress tolerance or is proline homeostasis a more critical issue? - Plant Cell Environ., 37(2): 300-311.

LIANG X., ZHANG L., NATARAJAN S.K., BECKER D.F., 2013 Proline mechanisms of stress survival - Antioxid. Redox Sign., 19(9): 998-1011.

LIN C.C., KAO C.H., 2002 - Osmotic stress-induced changes in cell wall peroxidase activity and hydrogen peroxide 
level in roots of rice seedlings. - J. Plant Growth Regul., 37: 177-183.

MAGGIO A., MIYAZAKI S., VERONESE P., FUJITA T., IBEAS J.I., DAMSZ B, NARASIMHAN M.L., HASEGAWA P.M., JOLY R.J., BRESSAN R.A., 2002 - Does proline accumulation play an active role in stress-induced growth reduction. - Plant J., 31: 699-712.

MANSOUR M.M.F., 2000 - Nitrogen containing compounds and adaptation of plants to salinity stress - Biol. Plant, 43(4): 491-500.

MARSCHNER H., 1995 - Functions of mineral nutrients: macronutrients, pp. 299-312. - In: MARSCHNER H. Mineral nutrition of higher plants. Second edition, Academic Press, NY, USA, pp. 651.

MENGEL K., KIRKBY E.A., 2001 - Principles of plant nutrition. Fifth edition. - Kluwer Academic Publishers, Dordrecht, The Netherlands, pp. 864.

OERKE E.C., DEHNE H.W., 2004 - Safeguarding productionlosses in major crops and the role of crop protection Crop Prot., 23: 275-285.

POSPISILOVA J., SYNKOVA H., RULCOVA J., 2000 - Cytokinin and water stress. - Biol. Plant., 43: 321-328.

REDMAN R.S., YO K., WOODWARD C.J.D.A., GREER C., ESPINO L., 2011 - Increased fitness of rice plants to abiotic stress via habitat adapted symbiosis: A strategy for mitigating impacts of climate change. - PLoS ONE, 6(7): e14823.

SANGAKKARA U.R., FREHNER M., NOSBERGER J., 2000 Effect of soil moisture and potassium fertilizer on shoot water potential, photosynthesis and partitioning of carbon in mung bean and cowpea .- J. Agron. Crop Sci., 185: 201-207.

SIRIPHANICH J., KADER A.A., 1985 - Effects of $\mathrm{CO}_{2}$ on total phenolics, phenylalanine ammonia lyase, and polyphenol oxidase in lettuce tissue. - J. Amer. Soc. Hort. Sci., 110(2): 249-253.

WANG M., ZHENG Q., SHEN Q., GUA S., 2013 - The critical role of potassium in plant stress response. - Int. J. Mol. Sci., 14: 7370-7390.

WEI J., LI C., LI Y., JIANG G., CHENG G., ZHENG Y., 2013 Effects of external potassium (K) supply on drought tolerances of two contrasting winter wheat cultivars. PLoS ONE, 8(7): e69737.

YASMEEN A., SHAHZAD M.A., ABDUL-WAHID B., FAROOQ M., HAFEEZ-UR-REHMAN N., HUSSAIN N., 2013 Improving drought resistance in wheat (Triticum aestivum) by exogenous application of growth enhancers. Int. J. Agric. Biol., 15: 1307-1312. 
